\title{
REVIEW: KONSERVASI KEANEKARAGAMAN HAYATI MELALUI TANAMAN OBAT DALAM HUTAN DI INDONESIA DENGAN TEKNOLOGI FARMASI: POTENSI DAN TANTANGAN
}

\author{
Ardiyanto W Nugroho \\ Correspoding author email: ardiyanto.nugroho@gmail.com
}

\begin{abstract}
ABSTRAK
Keanekaragaman hayati yang terdapat di hutan Indonesia termasuk yang paling tinggi di dunia. Meskipun demikian, program konservasi di Indonesia dirasakan belum optimal karena berbagai masalah seperti pembalakan liar, alih fungsi lahan dan kebakaran hutan. Salah satu upaya potensial yang bisa ditempuh untuk konservasi sumberdaya hayati adalah melalui aplikasi teknologi farmasi. Hal ini karena teknologi farmasi akan mendorong upaya pemanfaatan sumberdaya hutan, salah satunya tumbuhan obat, sehingga kebermanfaatan sumberdaya tersebut diketahui oleh masyarakat luas. Penelitian ini dilakukan untuk mengetahui potensi dan tantangan penggunaan teknologi farmasi untuk konservasi keanekaragaman hayati. Penelitian ini dilakukan dengan memanfaatkan data statistik kehutanan dari Kementerian Kehutanan untuk mengetahui potensi sumberdaya hayati dalam hutan Indonesia. Selain itu, analisis literatur secara kritis juga dilakukan untuk mengetahui potensi pemanfaatan keanekaragaman hayati dalam bidang farmasi. Selain itu, analisis isi juga dilakukan untuk menganalisis beberapa peraturan yang berhubungan dengan upaya pemanfaatan sumberdaya tersebut. Hasil penelitian menyebutkan bahwa luas kawasan hutan konservasi di negara ini adalah 27.4 juta ha, yang terdiri dari 50 taman nasional, 250 cagar alam, 75 suaka margasatwa, 115 taman wisata alam, 23 taman hutan raya dan 13 taman buru serta kawasan perairan laut. Selain itu, berbagai jenis tumbuhan obat tradisional sebenarnya telah lama dimanfaatkan oleh penduduk Indonesia yang tinggal disekitar maupun di pedalaman hutan. Selain itu, beberapa peraturan telah menyatakan komitmen pemerintah untuk memberikan kesempatan kepada masyarakat untuk memanfaatkan kawasan hutan untuk kepentingan farmasi, seperti Peraturan Pemerintah No 6 tahun 2007 tentang Tata Hutan dan Penyusunan Rencana Pengelolaan Hutan, serta Pemanfaatan Hutan, Peraturan Pemerintah No. 8 tahun 1999 tentang Pemanfaatan Jenis Tumbuhan dan Satwa Liar dan Undang Undang No 11 tahun 2013 tentang Protokol Nagoya. Sedangkan, strategi untuk meningkatkan upaya konservasi melalui teknologi farmasi adalah mensinkronkan penelitian etnobotani kehutanan dengan teknologi farmasi, kerjasama dengan luar negeri, dan melalui pendidikan dan pelatihan.
\end{abstract}

Kata kunci : konservasi, keanekaragaman hayati, farmasi, tanaman obat

Submitted on:4 April 2017

Accepted on: 7 July 2017

DOI: https://doi.org/10.25026/jsk.v1i7.71

\section{PENDAHULUAN}

Keanekaragaman hayati yang terdapat pada berbagai jenis hutan di Indonesia termasuk yang paling tinggi di dunia. Indonesia, melalui kementerian kehutanan mengelola kawasan hutan yang ditujukan untuk konservasi yang sangat luas. Data dari Ministry of Environment and Forestry (2015) meyebutkan bahwa luas kawasan hutan konservasi di negara ini adalah 27.4 juta ha, yang terdiri dari 50 taman nasional,
250 cagar alam, 75 suaka margasatwa, 115 taman wisata alam, 23 taman hutan raya dan 13 taman buru serta kawasan perairan laut. Sebagian dari wilayah tersebut dikelola bekerja sama dengan pemerintah daerah, seperti pada pengelolaan taman hutan raya. Meskipun demikian, program konservasi di Indonesia dirasakan belum optimal karena berbagai masalah seperti pembalakan liar, alih fungsi lahan dan kebakaran hutan. Penelitian yang 
dilakukan oleh Margono et al. (2014) menyebutkan bahwa dalam kurun waktu 2000 dan 2012, Indonesia kehilangan sejumlah 6.02 juta ha hutan, dan pada tahun 2012 tingkat deforestasi tahunan mencapai 0.82 juta ha per tahun. Masalah tersebut berdampak negatif terhadap biodiversitas flora dan fauna yang berada di kawasan konservasi tersebut.

Salah satu upaya potensial yang bisa ditempuh untuk konservasi sumberdaya hutan adalah melalui aplikasi teknologi farmasi. Hal ini karena teknologi farmasi akan mendorong upaya pemanfaatan sumberdaya hutan, salah satunya tumbuhan obat, sehingga kebermanfaatan sumberdaya tersebut diketahui oleh masyarakat luas. Dengan diketahuinya manfaat tumbuhan obat tersebut maka keinginan untuk mengkonservasi jenis tumbuhan tersebut semakin tinggi. Dilain pihak, hutan dengan keanekaragaman hayatinya yang tinggi merupakan salah satu sumber utama tanaman obat tradisional, dimana pemanfaatannya sudah berlangsung lama bahkan sampai dengan ratusan tahun. Sebagai tambahan, saat ini juga permintaan terhadap tumbuhan obat untuk industry farmasi di dalam negeri semakin meningkat. Bahkan, industri farmasi dari luar negeri juga sedang mencari potensi tumbuhan obat di Negara berkembang termasuk Indonesia. Oleh karena itu, kefarmasian memegang peranan potensial untuk usaha konservasi sumberdaya hutan di Indonesia.

Tulisan ini akan memaparkan pentingnya teknologi farmasi untuk konservasi sumberdaya hutan, dalam hal ini tumbuh-tumbuhan yang hidup didalam ekosistem hutan. Pada bagian pertama akan dijelaskan tentang potensi tumbuhan obat di hutan Indonesia. Kemudian, perkembangan industri berbasis tanaman obat akan didiskusikan, selanjutnya status penelitian untuk mendukung upaya konservasi dengan teknologi farmasi juga akan dibahas beserta regulasi-regulasi yang terkait. Terakhir, strategi-strategi alternatif untuk meningkatkan upaya konservasi melalui teknologi farmasi juga akan dibahas dalam tulisan ini.

\section{Potensi Tumbuhan Obat Di Hutan Indonesia}

Potensi tumbuhan obat di kawasan hutan Indonesia sangat tinggi karena tingginnya tingkat keanekaragaman hayati terutama pada hutan tropis yang belum teridentifikasi. Selain itu, di Indonesia masih terdapat sejumlah hutan primer yang masih terjaga kondisinya yang relatif masih luas. Sebagai ilustrasi, saat ini terdapat sekitar 9600 spesies tumbuhan yang diketahui mempunyai khasiat obat, namun hanya sekitar 200 spesies saja yang dimanfaatkan sebagai bahan baku untuk industri obat tradisional (Herdiani, 2012). Penelitian lain yang dilakukan oleh Galingging (2007) menyebutkan bahwa didaerah pedalaman Kalimantan Tengah terdapat potensi tumbuhan obat yang telah dimanfaatkan lama oleh masyarakat lokal. Penelitian tersebut juga menyebutkan bahwa tumbuhan 'bawang hantu' mengandung fitokimia alkaloid, glikosida, flavonoid, fenolik dan tannin yang dapat dipanen dalam umur 2-3 bulan. Penelitian lain yang dilakukan oleh Zuhud (2009) menyebutkan bahwa terdapat setidaknya 2000 spesies tumbuhan obat yang terdapat pada berbagai jenis hutan di Indonesia, dimana sekitar 772 spesies tumbuhan obat tersebut terdapat di hutan tropis, bagianbagian tumbuhan yang dimanfaatkan mulai dari daun, akar, batang, buah, biji sampai dengan air batangnya.

Berbagai jenis tumbuhan obat tradisional sebenarnya telah lama dimanfaatkan oleh penduduk Indonesia 
yang tinggal disekitar maupun di pedalaman hutan. Sebagai contoh, Hidayat and Hardiansyah (2013) melaporkan bahwa terdapat sekitar 25 jenis tumbuhan obat yang telah digunakan oleh masyarakat Dayak di Kalimantan Barat untuk menyembuhkan berbagai macam penyakit seperti bisul, sakit perut, penurun panas dan malaria. Selain itu, masih banyak penyakitpenyakit lainnya yang belum ditemukan obatnya seperti AIDS, kanker, stroke, epilepsy dan lainnya, yang masih perlu dilakukan eksplorasi untuk mencari tumbuhan obat yang berpotensi untuk mengobati penyakit tersebut. Oleh karena itu, potensi hutan di Indonesia sebagai sumber keanekaragaman hayati untuk menyediakan tumbuhan potensial obat sangat tinggi.

Luas kawasan hutan di Indonesia cukup signifikan sebagai penyedia tumbuhan obat potensial. Menurut statistik kehutanan yang diterbitkan oleh Ministry of Environment and Forestry (2015) luas total kawasan konservasi di Indonesia adalah 27.4 juta ha, hutan lindung 29.6 juta ha, hutan produksi terbatas 26.8 juta ha, hutan produksi tetap 29.2 juta ha dan hutan produksi konversi 13.1 juta ha. Hutan-hutan tersebut tersebar di seluruh Indonesia, dalam beberapa tipe ekosistem seperti hutan tropis, mangrove, hutan dataran tinggi, hutan rawa gambut dan hutan kerangas. Masing-masing ekosistem memiliki jenis tumbuhan dan satwa yang khas. Apabila dilihat dari jenis hutannya, hutan primer tercatat seluas 24.5 juta ha, hutan sekunder 24.2 juta ha dan 2.7 juta ha dalam bentuk hutan tanaman. Untuk pulau Kalimantan sendiri, hutan primer tercatat seluas 18.5 juta ha dan hutan sekunder seluas 32.3 juta ha. Hal ini mengindikasikan bahwa masih tersedia hutan dalam kondisi bagus untuk dilakukan eksplorasi potensi tumbuhan obat.

\section{Perkembangan Industri Farmasi Berbasis Bahan Alami Di Indonesia}

Potensi perkembangan industri farmasi dengan memanfaatkan tumbuhan obat tradisional sangat tinggi di Indonesia. Hal ini terjadi salah satunya karena perubahan pola hidup manusia untuk mulai mengkonsumsi obat-obatan dari bahan alami dan mengurangi konsumsi obat-obatan kimiawi, sesuai dengan konsep kembali ke alam (back to nature). Penyebab lain adalah mahalnya obat-obatan kimiawi modern sehingga pilihan alternatih obat herbal dengan bahan alami menjadi pilihan (Herdiani, 2012). Oleh karena itu, terjadi peningkatan permintaan bahan-bahan alami untuk memenuhi kebutuhan pasar dan industri farmasi. Sebagai contoh, pada tahun 2002 hanya terdapat sejumlah 55 industri obat tradisional di Indonesia yang terdaftar di badan Pengawas Obat dan Makanan (POM), kemudian angka tersebut meningkat menjadi 291 industri pada tahun 2006 (Dewoto, 2007).

$$
\text { Penggunaan obat-obatan }
$$

tradisional telah terdiversifikasi menjadi beberapa produk tidak hanya jamu dan produk obat herbal melainkan juga kosmetik, suplemen makanan, sabun dan produk industri lainnya dengan nilai pasar yang sangat signifikan. Kementerian perdagangan melaporkan bahwa omzet industri kosmetik nasional dengan bahan alami pada tahun 2011 sebesar 7 triliun rupiah, sedangkan untuk produk herbal nasional telah mencapai 11 triliun pada tahun yang sama, sedangkan dilain pihak bahan baku kosmetik dengan bahan alami sebagian masih impor (Kementerian Perindustrian, 2016). Oleh karena itu, masih terbuka celah pemanfaatan untuk mengurangi impor bahan baku kosmetik tersebut dan 
menggantikannya dengan bahan lokal. Para pengusaha akan tertarik karena bahan dalam negeri akan lebih murah dibandingkan bahan impor karena biaya transport yang lebih kecil.

Pertumbuhan ekspor industri farmasi berbasis bahan alami di Indonesia juga meningkat. Kementerian Perdagangan melaporkan nilai ekspor obat herbal Indonesia pada tahun 2009 yang hanya senilai 11.7 juta US\$ meningkat menjadi hampir 2 kali lipat pada tahun 2013 menjadi 23.4 juta US\$, dengan pertumbuhan pertahun rata-rata 6.5\% (Kementerian Perdagangan, 2014). Meskipun demikian, laporan tersebut menyebutkan bahwa jahe mendominasi pasar ekspor obat herbal dengan proporsi 88.6\% pada periode januari-Juni 2014. Hal ini mengindikasikan bahwa masih terdapat pasar yang potensial bagi jenisjenis lain untuk diekspor. Di sisi lain, nilai impor obat herbal Indonesia fluktuatif dengan kecenderungan menurun. Laporan dari Kementerian Perdagangan (2014) melaporkan bahwa nilai impor obat herbal pada tahun 2009 adalah 1 juta US\$, meningkat drastis 17.9 juta US\$ pada tahun 2011, kemudian nilai tersebut turun ke 7.3 juta US\$ ditahun 2013. Negara terbesar asal impor obat herbal adalah China dengan presentase $51.5 \%$ diikuti oleh India dengan proporsi $17.8 \%$.

\section{Sejauh mana penelitian yang telah dilakukan untuk mendukung upaya konservasi melalui teknologi farmasi? \\ Saat ini, penelitian yang} dilakukan oleh lembaga penelitian kehutanan dalam hal ini Badan Penelitian dan Pengembangan Kehutanan untuk upaya konservasi tumbuhan alam hubungannya dengan kefarmasian salah satunya adalah pengenalan jenis-jenis tumbuhan yang berpotensi sebagai obat tradisional. Penelitian ini bersifat dokumentasi kearifan lokal dalam menggunakan tanaman obat tradisional yang telah dipraktekkan oleh masyarakat tradisional secara turun temurun di berbagai tempat di Indonesia seperti di Dieng (Abdiyani, 2016), Kalimantan Timur (Setyowati, 2010), Jambi (Rahayu et al., 2007) maupun di Sulawesi (Rahayu et al., 2006).

Penelitian yang bertujuan mendokumentasikan aplikasi tanaman hutan sebagai obat tradisional sangat penting karena penggunaan tanaman hutan untuk obat tradisional sudah dikhawatirkan semakin menurun dari generasi ke generasi. Generasi sekarang kurang berminat dalam mempelajari metode pengobatan tradisional yang telah dipraktekkan oleh para pendahulu mereka. Akibatnya, pengetahuan yang berharga yang dimiliki oleh praktisi obat tradisional pada masyarakat pedalaman berpotensi hilang. Oleh karena itu penelitian yang bersifat etnobotani untuk mencatat jenis-jenis tumbuhan tradisional yang berguna untuk obat adalah sangat fundamental.

Cabang ilmu pengetahuan yang berperan dalam penelitian mengenai aplikasi obat tradisional adalah etnobotani. Dalam penelitian etnobotani, penggunaan tanaman obat yang telah digunakan selama bertahun-tahun oleh suku-suku tradisional akan dicatat dan dideskripsikan secara detail dan komprehensif. Penelitian ini belum maksimal mengingat sedikitnya jumlah peneliti yang tertarik dalam dunia etnobotani. Dilain pihak, jumlah sukusuku tradisional yang hidup di ribuan pulau di Indonesia sangat banyak. Apabila tren penurunan penggunaan obat tradisional masih terjadi dan cenderung semakin parah, maka potensi hilangnya informasi kearifan lokal akan lebih besar kedepannya. 
Meskipun demikian, memusatkan perhatian terhadap penelitian etnobotani saja tidaklah cukup untuk mendukung upaya konservasi. Hal ini karena masih banyak terdapat cabang ilmu lain yang juga penting untuk mendukung upaya konservasi sumberdaya hutan lainnya dalam kaitannya dengan teknologi farmasi seperti ilmu kimia dasar, biologi dan farmasi itu sendiri. Beberapa cabang ilmu tersebut harus saling bekerja sama dan bersinergi untuk menghasilkan penelitian yang komprehensif dan menyeluruh.

\section{Sejauh mana kebijakan pemerintah dalam mendukung upaya konservasi melalui teknologi farmasi?}

Regulasi yang diterbitkan oleh pemerintah dalam kaitannya dengan pemanfaatan hutan untuk kepentingan farmasi adalah Peraturan Pemerintah No 6 tahun 2007 tentang Tata Hutan dan Penyusunan Rencana Pengelolaan Hutan, serta Pemanfaatan Hutan. Dalam peraturan ini, pemanfaatan sumberdaya hutan untuk kepentingan farmasi, yaitu budidaya tanaman obat bisa dikategorikan dalam pemanfaatan hutan bukan kayu. Jenis kawasan yang bisa dimanfaatkan yaitu pada hutan lindung dan hutan produksi. Sedangkan untuk kawasan konservasi, pemanfaatan hasil hutan bukan kayu diatur dalam Peraturan Pemerintah No 28 tahun 2011 tentang Pengelolaan Kawasan Suaka Alam dan Kawasan Pelestarian Alam. Peraturanperaturan tersebut menyatakan komitmen pemerintah untuk memberikan kesempatan kepada masyarakat untuk memanfaatkan kawasan hutan untuk kepentingan farmasi.

Peraturan penting lainnya, yang menyatakan bahwa pemanfaatan sumberdaya hutan harus sesuai dengan prinsip kelestarian. Pada Peraturan Pemerintah No. 8 tahun 1999 tentang
Pemanfaatan Jenis Tumbuhan dan Satwa Liar, pada pasal 35 disebutkan bahwa 'Pemanfaatan jenis tumbuhan liar yang berasal dari habitat alam untuk keperluan budidaya tanaman obat-obatan dilakukan dengan tetap memelihara kelangsungan potensi, populasi, daya dukung, dan keanekaragaman jenis tumbuhan liar'. Hal tersebut mengindikasikan bahwa pemanfaatan hutan untuk kepentingan farmasi harus sesuai dengan prinsip konservasi.

Dalam konteks internasional, pemerintah juga telah menyatakan komitmennya dalam upaya konservasi sumberdaya hayati melalui pemanfaatan sumberdaya genetic yang diatur dalam Undang Undang No 11 tahun 2013 tentang Protokol Nagoya. Peraturan tersebut merupakan pernyataan ratifikasi atau dukungan Indonesia terhadap protocol Nagoya tentang Convention on Biological Diversity (konvensi keanekaragaman biologi), dalam hal ini terutama tentang akses pada Sumberdaya Genetik dan Pembagian Keuntungan yang Adil dan Seimbang yang Timbul dari Pemanfaatannya Atas Konvensi Keanekaragaman Hayati. Dengan meratifikasi protocol Nagoya tersebut, pemerintah mendapatkan berbagai manfaat positif salah satunya adalah menciptakan peluang untuk alih teknologi pada kegiatan konservasi dan pemanfaatan keanekaragaman hayati secara berkelanjutan. Mengingat Indonesia masih merupakan Negara yang berkembang, alih teknologi tersebut akan mempercepat penggunaan teknologi bagi masyarakat untuk upaya koservasi melalui kepentingan farmasi. Sehingga, tujuan-tujuan konservasi sumberdaya hutan bisa tercapai. 


\section{Bagaimana langkah-langkah strategis yang perlu dilakukan untuk mendukung upaya konservasi melalui teknologi farmasi?}

Mensinkronkan

penelitian

etnobotani kehutanan dengan teknologi farmasi merupakan salah satu cara untuk meningkatkan upaya konservasi keanekaragaman hayati. Hal ini karena kedua bidang tersebut saling membutuhkan satu dengan yang lainnya. Penelitian etnobotani hanya akan menjadi dokumentasi saja tanpa ada upaya penelitian lanjutan untuk membuktikan khasiat tumbuhan obat tradisional sekaligus upaya budidaya jenis tanaman tersebut untuk upaya konservasi. Setelah penelitian etnobotani, perlu dilakukan penelitian lanjutan agar obat tersebut digunakan dalam pelayanan kesehatan seperti dokter dan klinik untuk membuktikan secara ilmiah mengenai khasiat dan keamanan obat tradisional tersebut, antara lain dengan beberapa tahap; tahap seleksi; uji preklinik yang meliputi uji toksisitas dan farmakodinamik; standardisasi sederhana yaitu pembuatan sediaan terstandar; dan uji klinik (Dewoto, 2007). Kemudian apabila suatu jenis tumbuhan telah dikenal dengan khasiatnya maka secara langsung akan dibudidayakan oleh masyarakat dan industry. Apabila suatu jenis tumbuhan tersebut merupakan jenis yang langka, maka upaya budidaya merupakan tindakan konservasi.

Usaha strategis lain dalam upaya konservasi keanekaragaman hayati dengan teknologi farmasi adalah dengan kerjasama dengan luar negeri. Sebagai contoh adalah bioprospeksi tumbuhan obat bekerjasama dengan perusahaan internasional dari luar negeri. bioprospeksi (bioprospecting) merupakan penelusuran sistematik, klasifikasi, dan investigasi untuk tujuan komersial dari sumber senyawa kimia baru, gen, protein, mikroorganisme, dan produk lain dengan nilai ekonomi aktual dan potensial, yang ditemukan dalam keanekaragaman hayati. Salah satu contoh negara yang relative telah sukses dalam mengimplementasikan bioprospeksi tumbuhan obat adalah Kosta Rika yang bekerja sama dengan perusahaan Merck \& Co (Campbell, 2002). Dalam skema kerja sama tersebut, pemerintah Kosta Rika melalui National Institute of Biodiversity (INBio) memberikan sampel-sampel biologis dari hutan di negara tersebut kepada perusahaan Merck \& Co dengan imbalan sejumlah dana untuk upaya konservasi dan royalty penjualan serta fasilitas penelitian untuk Kosta Rika.

Upaya yang lain untuk konservasi keanekaragaman hayati dengan teknologi farmasi adalah dengan pendidikan dan pelatihan kepada para peneliti atau pun praktisi lainnya untuk meningkatkan skill dan pengalaman mereka yang dilakukan oleh pemerintah. Selanjutnya, perlu juga dibangun fasilitas-fasilitas penelitian dan laboratorium yang memadai terutama untuk penelitian yang berhubungan dengan farmasi. Hal ini karena penelitian yang berhubungan dengan kefarmasian memerlukan fasilitas penelitian yang relatif canggih dengan dana yang relatif besar.

\section{KESIMPULAN}

Teknologi farmasi dapat digunakan sebagai salah satu cara untuk konservasi keanekaragaman hayati di Indonesia. Hal ini karena teknologi farmasi akan mendorong upaya pemanfaatan sumberdaya hutan, salah satunya tumbuhan obat, sehingga kebermanfaatan sumberdaya tersebut diketahui oleh masyarakat luas. Dengan diketahuinya manfaat tumbuhan obat tersebut maka keinginan untuk mengkonservasi jenis tumbuhan tersebut 
semakin tinggi. Upaya tersebut didukung oleh komitmen pemerintah melalui berbagai regulasi yang telah diterbitkan, potensi tumbuhan obat yang sangat besar di negara ini yang tersimpan dalam kawasan hutan yang relatif luas, dan adanya pangsa pasar industri obat tradisional yang semakin berkembang. Sedangkan, strategi untuk meningkatkan upaya konservasi melalui teknologi farmasi adalah mensinkronkan penelitian etnobotani kehutanan dengan teknologi farmasi, kerjasama dengan luar negeri, dan melalui pendidikan dan pelatihan.

\section{DAFTAR PUSTAKA}

[1]. Abdiyani, S. 2016. Keanekaragaman jenis tumbuhan bawah berkhasiat obat di dataran tinggi Dieng. Jurnal Penelitian Hutan dan Konservasi Alam, 5, 79-92.

[2]. Campbell, L. M. 2002. Conservation narratives in Costa Rica: conflict and co-existence. Development and Change, 33, 29-56.

[3]. Dewoto, H. R. 2007. Pengembangan obat tradisional Indonesia menjadi fitofarmaka. Majalah Kedokteran Indonesia, 57, 205211.

[4]. Galingging, R. Y. 2007. Potensi plasma nutfah tanaman obat sebagai sumber biofarmaka di Kalimantan Tengah. Jurnal Pengkajian dan Pengembangan Teknologi Pertanian, 10, 76-83.

[5]. Herdiani, E. 2012. Potensi Tanaman Obat Indonesia [Online]. Indonesia: BBPP Lembang. Available: http://www.bbpplembang.info/index.php/arsip/artikel/artikelpertanian/585-potensi-tanaman-obatindonesia [Accessed 10 April 2017].

[6]. Hidayat, D. \& Hardiansyah, G. 2013. Studi keanekaragaman jenis tumbuhan obat di kawasan IUPHHK PT. Sari Bumi Kusuma camp Tontang Kabupaten Sintang.
[7]. Kementerian Perdagangan 2014. Obat Herbal Tradisional. Warta Ekspor. Jakarta: Ditjen PEN.

[8]. Kementerian perindustrian. 2016. Industri Herbal Indonesia Berprospek Cerah [Online]. Jakarta: Kementerian Perindustrian. Available: http://www.kemenperin.go.id/artikel/3109/I ndustri-Herbal-Indonesia-Berprospek-Cerah [Accessed 10 April 2017].

[9]. Margono, B. A., Potapov, P. V., Turubanova, S., Stolle, F. \& Hansen, M. C. 2014. Primary forest cover loss in Indonesia over 2000-2012. Nature Climate Change, 4, 730-735.

[10]. Ministry Of Environment And Forestry 2015. Statistik Kementerian Lingkungan Hidup dan Kehutanan Tahun 2014 (Statistics of Ministry of Environment and Forestry 2014). Yearly. December 2015 ed. Jakarta, Indonesia: Ministry of Environment and Forestry.

[11]. Rahayu, M., Sunarti, S., Sulistiarini, D. \& Prawiroatmodjo, S. 2006. Pemanfaatan tumbuhan obat secara tradisional oleh masyarakat lokal di Pulau Wawonii, Sulawesi Tenggara. Biodiversitas, 7, 245250.

[12]. Rahayu, M., Susiarti, S. \& Purwanto, Y. 2007. Kajian pemanfaatan tumbuhan hutan non kayu oleh masyarakat lokal di kawasan konservasi PT. Wira Karya Sakti Sungai Tapa-Jambi. Jurnal Biodiversitas, 8, 73-78.

[13]. Setyowati, F. M. 2010. Etnofarmakologi dan pemakaian tanaman obat suku dayak tunjung di Kalimantan Timur. Media Penelitian dan Pengembangan Kesehatan, 20.

[14]. Zuhud, E. A. 2009. Potensi hutan tropika Indonesia sebagai penyangga bahan obat alam untuk kesehatan bangsa. Jurnal Bahan Alam Indonesia, 6, 227-232. 